\title{
ANALISIS YURIDIS PERANAN PASAR MODAL SYARIAH DALAM MENDUKUNG PEMBANGUNAN EKONOMI YANG BERKELANJUTAN (SUISTANABLE AND RESPONSIBLE INVESTMENT) ${ }^{1}$
}

\author{
Helza Nova Lita \\ Fakultas Hukum Universitas Padjadjaran \\ Email : helzanova@yahoo.com
}

\begin{abstract}
As economy is growing rapidly, indicated by significant increase of goods and services, neglects such as environmental damage, social gap, and poverty prevail. These issues have been in the spotlight especially among conservationists. At the same time, another phenomenon-that Islamic economy is currently reviving in Indonesia - has been good news especially for Indonesian people dominated by Moslems. Syariah capital market can be simply defined as a capital market which applies syariah principles in all of its economic transaction aspects. Indonesian Stock Exchange (BEI)—in collaboration with PT Danareksa Investment Management-launched Jakarta Islamic Index (JII) on July 32000 in a bid to provide investors with guidance in their investment on the syariah basis.

In the practice of Syariah Capital Market, Bapepam which serves as the regulator in Indonesia, based on UU No.8 1995 on Capital Market, issued two decrees: Bapepam-LK No. Kep-130/BL/2006 and No. Kep-131/BL/2006. The institution has also issued a regulation package strongly related to the practice of Syariah Capital Market, i.e. Regulation No.IX.A.13 on Issuance of Sharia Securities and Regulation No.IX.A.14 on the supporting legal contracts. Issuers' business activities, including the ones related to the preservation of the environment, are parts of the implementation of their Syariah principles despite the fact that this has not been specifically stated in the Bapepam Regulations. Principally, any syariah instruments issued in Indonesia, including Mudharabah Syariah Bonds, Ijarah Syariah Bonds, Syariah Stocks, Syariah Mutual Funds, Syariah Index Mutual Funds, Issuance of Sharia Securities, must abide by Islamic values. This basic principle also applies to the commitment to preserving the environment.
\end{abstract}

Keywords : Syariah Capital Market, Sustainable Economic Development

\footnotetext{
${ }^{1}$ Hasil Penelitian Helza Nova Lita,S.H.,M.H., Dosen Tetap Fakultas Hukum Universitas Padjadjaran, dana DIPA FH UNPAD tahun anggaran 2011.
} 


\begin{abstract}
Abstrak
Disaat pertumbuhan ekonomi berkembang pesat menghasilkan barang dan jasa, namun tidak beriringan dengan tatanan lingkungan hidup yang rusak, terjadinya ketimpangan sosial, dan kemiskinan. Hal ini telah menjadi sorotan bagi para pelestari lingkungan. Bangkitnya ekonomi Islam di Indonesia dewasa ini menjadi fenomena yang menarik dan menggembirakan terutama bagi penduduk Indonesia yang mayoritas beragama Islam. Secara sederhana, pasar modal syariah dapat diartikan sebagai pasar modal yang menerapkan prinsip-prinsip syariah dalam kegiatan transaksi ekonominya. BEI bekerja sama dengan PT Danareksa Investment Management meluncurkan Jakarta Islamic Index (JII) pada tanggal 3 Juli 2000 yang bertujuan memandu investor yang ingin menanamkan dananya secara syariah.

Untuk kegiatan Pasar Modal Syariah, Bapepam sebagai pengatur dan pengawas pasar modal di Indonesia berdasarkan Undang-Undang Nomor 8 tahun 1995 tentang Pasal Modal telah menerbitkan Keputusan Ketua Bapepam-LK Nomor Kep-130/BL/2006 dan Nomor Kep-131/BL/2006 telah menerbitkan satu paket regulasi yang terkait dengan penerapan prinsip syariah di pasar modal, yaitu Peraturan Nomor IX.A.13 tentang Penerbitan Efek Syariah dan Peraturan Nomor IX.A.14 tentang Akad-akad yang digunakan dalam Penerbitan Efek Syariah di Pasar Modal. Kegiatan usaha emiten yang terkait dengan dukungannya terhadap kegiatan usaha ramah lingkungan merupakan bagian dari implementasi prinsipprinsip syariah meskipun dalam ketentuan pelaksanaan ekonomi syariah melalui keputusan BAPEPAM belum dinyatakan secara tegas.Pada prinsipnya, segala jenis instrumen emiten syariah yang diterbitkan di Indonesia saat ini yang meliputi Obligasi Syariah Mudharabah, Obligasi Syariah Ijarah, Saham Syariah, Reksa Dana Syariah, Reksa Dana Indeks Syariah, dan Penerbitan Efek Reksa Dana Syariah harus konsisten dengan implementasi nilai-nilai ekonomi Islam, termasuk pada komitmen penegakan kegiatan usaha yang ramah lingkungan.
\end{abstract}

Kata Kunci : Pasar Modal Syariah, Pembangunan Ekonomi Berkelanjutan

\title{
A. PENDAHULUAN
}

Meskipun berinvestasi di pasar modal belum sepopuler seperti halnya berinvestasi di sektor riil, pasar modal pada dasarnya merupakan bentuk investasi yang sangat menguntungkan. Sebagai gambaran, pasar modal Indonesia yang diwakili Indeks Harga Saham Gabungan (IHSG) di Bursa Efek Indonesia (BEI) sepanjang 2010 tumbuh 46,1\%. Kini IHSG telah menembus level 3.800 dengan kapitalisasi pasar Rp. 3.200 - Rp 3.300 triliun dan terus meningkat. Namun berhasilnya pasar modal serta ekonomi domestik ternyata tidak menguntungkan semua pihak. Disaat ekonomi tumbuh pesat menghasilkan barang dan jasa, justru 
lingkungan hidup semakin rusak dan timbul ketimpangan sosial dan kemiskinan. Hal ini telah menjadi pergumulan para pelestari lingkungan ${ }^{2}$.

Dalam menjembatani ketimpangan tersebut, pada bulan Juli 2009, Kehati bekerja sama dengan BEI meluncurkan indeks yang berpedoman pada Suistanable and Responsible Investment (SRI). Emiten yang masuk indeks tersebut tidak hanya menciptakan laba, tetapi juga pembangunan berkelanjutan yang berbasiskan enam fundamental. Enam hal itu pelestarian lingkungan, masyarakat, hak asasi manusia, perilaku bisnis, praktik ketenagakerjaan, dan kepatutan ${ }^{3}$.

Bangkitnya ekonomi Islam di Indonesia dewasa ini menjadi fenomena yang menarik dan menggembirakan terutama bagi penduduk Indonesia yang mayoritas beragama Islam. Praktek kegiatan ekonomi konvensional, khususnya dalam kegiatan pasar modal yang mengandung unsur spekulasi sebagai salah satu komponennya nampaknya masih menjadi hambatan psikologis bagi umat Islam untuk turut aktif dalam kegiatan investasi terutama di bidang pasar modal.

Pasar Modal Syariah secara resmi diluncurkan pada tanggal 14 Maret 2003 bersamaan dengan penandatanganan MOU antara BAPEPAM dengan Dewan Syariah Nasional - Majelis Ulama Indonesia. Walaupun secara resmi diluncurkan pada tahun 2003, namun instrumen pasar modal syariah telah hadir di Indonesia sejak tahun 1997. Hal ini ditandai dengan peluncuran Danareksa Syariah pada tanggal 03 Juli 1997 oleh PT Danareksa Investment Management. Selanjutnya BEI bekerja sama dengan PT Danareksa Investment Managemement. Selanjutnya, BEI bekerja sama dengan PT Danareksa Investment Management meluncurkan Jakarta Islamic Index (JII) pada tanggal 3 Juli 2000 yang bertujuan memandu investor yang ingin menanamkan dananya secara syariah.

\section{B. METODOLOGI PENELITIAN}

Metode yang digunakan dalam penelitian ini adalah metode penelitian yuridis normatif dengan pendekatan perundang-undangan dan konsep pasar modal dalam ekonomi Islam. Pendekatan perundang-undangan dilakukan dengan

\footnotetext{
${ }^{2}$ Andreas Timothy, "Berinvestasi Hijau di Lantai Bursa", Media Indonesia, Kamis 12 Mei 2011, hlm. 18.

${ }^{3}$ Ibid.
} 
menginventarisasi peraturan yang terkait dengan ketentuan pasar modal syariah yakni undang-undang nomor 8 tahun 1995 tentang Pasar Modal, beserta aturan pelaksanaannya dari BAPEPAM sebagai pengatur dan pengawas kegiatan pasar modal di Indonesia.

Penelitian ini dilakukan melalui Penelitian Kepustakaan (Library Research) untuk memperoleh bahan hukum primer berupa bahan hukum yang mengikat seperti peraturan perundang-undangan nasional khususnya dibidang pasar modal dan peraturan pelaksanaannya melalui Keputusan Bapepam serta peraturan yang terkait lainnya, bahan hukum sekunder yang meliputi referensi hukum dan non hukum berupa hasil penelitian, karya tulis dari kalangan hukum dan bahan-bahan hukum tersier berupa kamus, ensiklopedia dan berbagai artikel di media cetak.

Teknik pengumpulan data yang digunakan adalah studi dokumen. Studi dokumen dilakukan terhadap data sekunder untuk mendapatkan landasan teoritis. Pendapat-pendapat atau tulisan-tulisan para ahli atau pihak lain berupa informasi baik dalam bentuk formal maupun data melalui naskah resmi.

Analisis data dan penarikan kesimpulan dari hasil penelitian dilakukan dengan menggunakan metode kualitatif untuk selanjutnya disajikan dalam bentuk deskriptif analitis.

\section{PEMBAHASAN}

\section{Pengertian dan Konsep Ekonomi Islam}

Menurut M.Akram Khan pengertian Ekonomi Islam adalah: ${ }^{4}$

"Islamic economics aims to the study of human falah (well being) achieved by organizing the resources of the earth on the basic of cooperation and participation"

Ilmu ekonomi Islam bertujuan untuk melakukan kajian tentang kebahagiaan hidup manusia (human falah) yang dicapai dengan mengorganisasikan sumber daya alam atas dasar gotong royong dan partisipasi.

Prof. Dr. M. Umer Chapra mengatakan : ${ }^{5}$

\footnotetext{
${ }^{4}$ Mohammad Hidayat, An Introduction The Sharia Economic Pengantar Ekonomi Syariah, Zikrul Hakim, Cetakan Pertama : Februari 2010, Jakarta, ,hlm. 23.
} 
"Islamic economics was defined as that branch of knowledge which helps realize human well-being through an allocation and distribution of scare resources that is in conformity with Islamics teaching without unduly curbing individual freedom or creating continued macroeconomic and ecological imbalance”.

Ekonomi Islam didefinisikan sebagai sebuah pengetahuan yang membantu upaya realisasi kebahagiaan manusia melalui alokasi dan distribusi sumber daya yang terbatas dalam koridor yang mengacu pada pengajaran Islam tanpa memberikan kebebasan individu (laissez faire) atau tanpa perilaku makro yang berkesinambungan dan tanpa keseimbangan lingkungan"

Baik definisi ekonomi konvensional maupun ekonomi Islam, dalam banyak hal memiliki kesamaan, yakni sama-sama menyelidiki perilaku manusia dalam kegiatan produksi, distribusi, dan konsumsi yang menyangkut pilihan terhadap sumber daya tersebut guna memenuhi kebutuhan manusia. Tetapi dalam ekonomi Islam tujuan aktivitas ekonomi ditetapkan dengan jelas, tidak hanya mencapai kebahagiaan duniawi dan ukhrawi yang seimbang, tetapi juga untuk mewujudkan keadilan sosial ekonomi ${ }^{6}$.

Sumber - sumber hukum Islam termasuk didalamnya sumber - sumber hukum ekonomi Islam yang diakui oleh para Jumhur Ulama ${ }^{7}$ adalah Al - Qur'an, Sunnah Rasul atau Hadist, Ijmak, dan Qiyas. Al - Qur'an dan Sunnah Rasul menempati kedudukan utama dalam sumber hukum ekonomi Islam. Al - Qur'an merupakan firman Allah SWT yang disampaikan kepada manusia melalui Nabi Muhammad SAW. Sedangkan Sunnah, menurut para ilmu ahli hadist, sunnah identik dengan hadist, dan mereka mendefinisikannya dengan segala perkataan dan perbuatan, takrir, sifat, keadaan, tabiat / watak, dan perjalanan hidup nabi Muhammad baik yang berhubungan dengan masalah hukum maupun tidak ${ }^{8}$.

Filsafat ekonomi Islam didasarkan pada konsep Triangle yakni adanya filsafat Tuhan, Manusia, dan Alam. Jadi kunci filsafat ekonomi Islam terletak

${ }^{5}$ Ibid, hlm. 24.

${ }^{6} \mathrm{Ibid}, \mathrm{hlm} .27$.

${ }^{7}$ Muslimin H. Kara, Bank Syariah di Indonesia, Analisis Kebijakan Pemerintah Indonesia Terhadap Perbankan Syariah, UII Press, Yogyakarta, 2005, hlm. 26.

${ }^{8}$ Habib Nazir dan Muhammad Hassanuddin, Ensiklopedi Ekonomi dan Perbankan Syariah, Penerbit Kaki Langit, Bandung, November 2004, hlm. 532. 
pada manusia dengan Tuhan, alam dan manusia lainnya. Selain itu ekonomi Islam juga membahas tujuan hidup manusia di bumi ini.

Hubungan manusia dengan Tuhan dirumuskan dengan tauhid. Tauhid dalam wacana ekonomi Islam berarti bahwa semua sumber daya alam yang ada di semesta alam merupakan ciptaan dan milik Tuhan secara absolut. Konsep tauhid mengajarkan bahwa Allah itu Esa, pencipta segala mahluk yang diciptakan-NYA adalah manusia yang berasal dari substansi yang sama serta memiliki hak dan kewajiban yang sama sebagai khalifah Allah di muka bumi. Sumber daya alam, flora, dan fauna ditundukkan oleh Allah SWT sebagai sumber manfaat ekonomis bagi umat manusia (Q.S. Al - An'aam 142 - 145, An - Nahl : 10 -16).

\section{Pembangunan Ekonomi Berkelanjutan}

Secara konseptual, pengertian pembangunan berkelanjutan berasal dari ilmu ekonomi yang terutama di kaitkan dengan persoalan efisiensi dan keadilan (equity) untuk menjamin keberlanjutan pembangunan ekonomi bagi kesejahteraan masyarakat. Pengertian dari segi ekonomi ini juga dilatarbelakangi oleh ilmu biologi yang membahas keberlanjutan dari segi kemampuan dan kesesuaian (capability and surtability) suatu likasi dengan potensi regenerasi / produktivitas lingkungan hidupnya ${ }^{9}$.

Emil Salim memberikan rumusan pengertian Pembangunan Berkesinambungan (sustainable development) sebagai "suatu proses perubahan yang di dalamnya eksploitasi sumberdaya, arah investasi, orientasi pengembangan teknologi, dan perubahan kelembagaan semuanya dalam keadaan yang selaras serta meningkatkan potensi masa kini dan masa depan untuk memenuhi kebutuhan dan aspirasi manusia" ${ }^{\prime 10}$.

\footnotetext{
${ }^{9}$ Daud Silalahi, Pembangunan Berkelanjutan dalam ranka Pengelolaan (termasuk perlindungan) sumber daya alam yang berbasis Pembangunan Sosial dan Ekonomi, Makalah disampaikan pada Seminar Pembangunan Hukum Nasional VIII, Tema Penegakan Hukum dalam Era Pembangunan Berkelanjutan diselenggarakan oleh Badan Pembina Hukum Nasional Departemen Kehakiman dan Hak Asasi Manusia RI Denpasar, 14-18 Juli 2003. Hlm. 7.

${ }^{10}$ Emil Salim, Lingkungan Hidup, Mutiara Sumber Widya, 1985.
} 


\section{Pasar Modal Syariah}

Landasan ekonomi kekeluargaan menurut Pasal 33 UUD 1945 mempunyai kaitan erat dengan aktivitas pasar modal di Indonesia sebagaimana telah diatur dalam UU No. 8 tahun 1995 tentang Pasar Modal. Melalui kepemilikan sahamsaham perusahaan yang listing di pasar modal oleh masyarakat sebagai investor pasar modal, berarti memberikan kesempatan pemerataan dalam bidang ekonomi. Disamping itu perusahaan yang memerlukan tambahan dana bagi pembiayaan dan perluasan usahanya dapat mendapatkannya melalui penjualan atas saham perusahaan melalui mekanisme pasar modal.

Secara sederhana, pasar modal syariah dapat diartikan sebagai pasar modal yang menerapkan prinsip-prinsip syariah dalam kegiatan transaksi ekonomi dan terlepas dari hal-hal yang dilarang, seperti : riba, perjudian, spekulasi, dan lainlain $^{11}$

Untuk kegiatan Pasar Modal Syariah, Bapepam sebagai pengatur dan pengawas pasar modal di Indonesia berdasarkan Undang-Undang Nomor 8 tahun 1995 tentang Pasal Modal telah menerbitkan Keputusan Ketua Bapepam-LK Nomor Kep-130/BL/2006 dan Nomor Kep-131/BL/2006 telah menerbitkan satu paket regulasi yang terkait dengan penerapan prinsip syariah di pasar modal, yaitu Peraturan Nomor IX.A.13 tentang Penerbitan Efek Syariah dan Peraturan Nomor IX.A.14 tentang Akad-akad yang digunakan dalam Penerbitan Efek Syariah di Pasar Modal.

Dalam Lampiran Keputusan Ketua Bapepam dan LK Nomor : Kep130/BL/2006 Tanggal : 23 Nopember 2006 Peraturan Nomor IX.A.13 tentang Penerbitan Efek Syariah dijelaskan bahwa Prinsip-prinsip Syariah di Pasar Modal adalah Prinsip-prinsip hukum Islam dalam kegiatan di bidang Pasar Modal berdasarkan fatwa Dewan Syariah Nasional Majelis Ulama Indonesia (DSNMUI), baik fatwa DSN-MUI yang ditetapkan dalam peraturan Bapepam dan LK maupun fatwa DSN-MUI yang telah diterbitkan sebelum ditetapkannya peraturan

\footnotetext{
${ }^{11}$ Tjiptono Darmadji dan Hendi M. Fakhrudin, Pasar Modal di Indonesia pendekatan tanya jawab, Penerbit Salemba Empat, Edisi 2, Cetakan ke- 3 Maret 2008, Jakarta, hlm. 231.
} 
ini, sepanjang fatwa dimaksud tidak bertentangan dengan peraturan ini dan atau Peraturan Bapepam dan LK lain yang didasarkan pada fatwa DSN-MUI.

Dalam Keputusan Ketua Badan Pengawas Pasar Modal dan Lembaga Keuangan Nomor : Kep - 130/BL/2006 tentang Penerbitan Efek Syariah, Efek Syariah adalah Efek sebagaimana dimaksud dalam Undang-undang Pasar Modal dan peraturan pelaksanaannya yang akad maupun cara penerbitannya memenuhi Prinsip-prinsip Syariah di Pasar Modal.

Kegiatan usaha yang terkait dalam efek syariah Dalam Keputusan Ketua Badan Pengawas Pasar Modal dan Lembaga Keuangan Nomor : Kep 130/BL/2006 harus memenuhi dan tidak bertentangan dengan prinsip - prinsip syariah.Kegiatan usaha yang bertentangan dengan Prinsip - prinsip Syariah antara lain:

1. Perjudian dan permainan yang tergolong judi atau perdagangan yang dilarang;

2. menyelenggarakan jasa keuangan yang menerapkan konsep ribawi, jual beli risiko yang mengandung gharar dan atau maysir;

3. memproduksi, mendistribusikan, memperdagangkan, dan atau menyediakan:

a) barang dan atau jasa yang haram karena zatnya (haram li-dzatihi);

b) barang dan atau jasa yang haram bukan karena zatnya (haram lighairihi) yang ditetapkan oleh DSN-MUI; dan atau

c) barang dan atau jasa yang merusak moral dan bersifat mudarat; dan atau melakukan investasi pada perusahaan yang pada saat transaksi tingkat (nisbah) hutang perusahaan kepada lembaga keuangan ribawi lebih dominan dari modalnya, kecuali investasi tersebut dinyatakan kesyariahannya oleh DSN-MUI.

Di Indonesia, prinsip - prinsip penyertaan modal secara syariah tidak diwujudkan dalam bentuk saham syariah maupun non syariah, melainkan berupa pembentukan indeks saham yang memenuhi prinsip-prinsip syariah.

Di Bursa Efek Indonesia ada Jakarta Islamic Indeks (JII) yang merupakan saham-saham yang termasuk kategori syariah. JII dimaksudkan digunakan sebagai 
tolok ukur (benchmark) kinerja suatu investasi saham dengan basis syariah. Penentuan kriteria pemilihan saham dalam JII melibatkan pihak Dewan Pengawas Syariah PT. Danareksa Investment Management.

Langkah untuk mendorong emiten saham menggembangkan ekonomi yang ramah lingkungan telah memberikan pilihan bagi fund manager untuk menawarkan produk green economy bagi investor. Pada Bulan Juli tahun 2009 KEHATI bekerjasama dengan BEI telah meluncurkan Indeks SRI KEHATI yang berpedoman pada Sustainable and Responsible Investment (SRI). Indeks ini berisikan perusahaan-perusahaan yang kinerjanya turut andil kepedulian terhadap lingkungan hidup, sosial dan tata kelola perusahaan yang baik (good corporat governance / GCG) ${ }^{12}$.

Emiten-emiten yang masuk kategori ini tidak hanya menciptakan laba, namun juga melakukan upaya-upaya pembangunan berkelanjutan yang berbasiskan pada enam fundamental, yaitu pelestarian lingkungan, masyarakat, corporate governance, human rights, business behavior serta labour practice dan decent work. Saat ini sebanyak 25 saham di BEI telah masuk ke dalam kategori indeks SRI KEHATI. Emiten saham yang direviuw pada periode Mei - Oktober 2011 ini telah melalui dua kali penyaringan untuk bisa masuk pada indeks yang dimaksud. Sebagian besar emiten yang masuk ke dalam indeks "hijau" tersebut, tergolong emiten dengan saham likuid, antara lain PT Astra International Tbk (ASII), PT Bank Mandiri Tbk (BMRI), PT Bank Negara Indonesia Tbk (BBNI), PT Bank Rakyat Indonesia Tbk (BBRI), PT Indocement Tunggal Perkasa Tbk (INTP) dan PT Telekomunikasi Indonesia Tbk (TLKM) ${ }^{13}$.

Munculnya gerakan sadar akan pembangunan ekonomi berkelanjutan dan ramah lingkungan sangat selaras dengan prinsip-prinsip yang dibangun dalam ekonomi Islam. Filsafat ekonomi Islam yang didasarkan pada konsep "Triangle" yakni filsafat Tuhan, Manusia, dan alam, sangat berkaitan dan tak terpisahkan. Konsep ekonomi ketuhanan dalam Islam berkaitan dengan konsep tauhid dalam wacana ekonomi bahwa semua sumber daya alam semesta merupakan ciptaan

\footnotetext{
${ }^{12}$ Indeks Sri Kehati : Investasi Ramah Lingkungan,

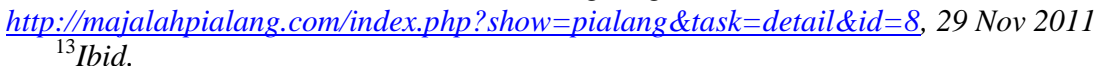


Tuhan dan milik Allah SWT secara absolut dan manusia sebagai khalifah diberikan amanah untuk menjaga dan mengelolanya sesuai dengan aturan-NYA, agar mencapai kesejahteraan duniawi dan ukhrawi serta keseimbangan untuk mencapai keadilan sosial dalam masyarkat, serta menghindari segala bentuk kerusakan dalam sistem ekonomi dan lingkungan alam.

Kegiatan usaha yang terkait dalam efek syariah demikian pula harus terkait memenuhi dan tidak bertentangan dengan prinsip-prinsip syariah sebagaimana yang dituangkan dalam Dalam Keputusan Ketua Badan Pengawas Pasar Modal dan Lembaga Keuangan Nomor : Kep - 130/BL/2006, diantaranya bahwa yang termasuk kegiatan usaha yang bertentangan dengan Prinsip-prinsip Syariah antara lain : memproduksi, mendistribusikan, memperdagangkan, dan atau menyediakan: barang dan atau jasa yang haram karena zatnya (haram li-dzatihi); barang dan atau jasa yang haram bukan karena zatnya (haram lighairihi) yang ditetapkan oleh DSN-MUI; dan atau barang dan atau jasa yang merusak moral dan bersifat mudarat; dan atau melakukan investasi pada perusahaan yang pada saat transaksi tingkat (nisbah) hutang perusahaan kepada lembaga keuangan ribawi lebih dominan dari modalnya, kecuali investasi tersebut dinyatakan kesyariahannya oleh DSN-MUI. Dalam ketentuan ini memang tidak secara tegas dinyatakan tentang usaha atau jasa yang melanggar atau tidak ramah lingkungan. Namun penafsiran secara lebih luas bahwa larangan terhadap barang atau juasa yang bersifat mudharat dalam ketentuan tersebut termasuk kategori emiten-emiten yang terbukti dalam operasional kegiatan usahanya menimbulkan mudharat, termasuk menimbulkan pencemaran dan tidak ramah lingkungan yang merugikan ekosistem disekitarnya.

Dalam penafsiran yang lebih luas bahwa efek-efek syariah yang diterbitkan di Pasar Modal harus memenuhi prinsip - prinsip syariah. Salah satu pilar etika bisnis Islam yang tertuang dalam ketentuan Al - Qur'an adalah prinsip "Keseimbangan dan Keadilan" berarti bahwa perilaku bisnis harus seimbang dan adil. Keseimbangan berarti tidak berlebihan dalam mengejar keuntungan ekonomi sebagaimana yang tertuang dalam surat Al - A'raaf ayat 31, demikian pula adanya keseimbangan bahwa harta mempunyai fungsi sosial sebagaimana tertuang dalam 
Surat Adz - Dzaariyaat ayat :19, serta sesuai filosofi ekonomi Islam yang memuat triangle konsep ketuhanan, manusia dan alam, diantaranya adalah keseimbangan dan ramah lingkungan sebagaimana yang telah di ingatkan dalam Al - Qur'an surat : Ar - Rum ayat : 41 bahwa :

"Telah nyata kerusakan di darat dan dilaut,disebabkan usaha tangan manusia, karena Allah hendak membuat mereka merasakan sebagian dari akibat perbuatan mereka, supaya mereka kembali”

Kegiatan usaha emiten yang terkait dengan dukungannya terhadap kegiatan usaha ramah lingkungan merupakan bagian dari implementasi prinsip-prinsip syariah meskipun dalam ketentuan pelaksanaan ekonomi syariah melalui keputusan BAPEPAM belum dinyatakan secara tegas.

Aspek-aspek penggembangan kegiatan usaha yang ramah lingkungan melalui instrumen pasar modal diatas pada dasarnya merupakan bagian yang tak terpisah dari implementasi prinsip-prinsip syariah.

Mengacu pada Keputusan Ketua Badan Pengawas Pasar Modal dan Lembaga Keuangan Nomor : Kep - 130/BL/2006, Penerbitan Efek Syariah sesuai dengan Keputusan Bapepam wajib dilakukan berdasarkan Akad Syariah. Setiap Pihak yang melakukan penerbitan Efek Syariah wajib memenuhi Prinsip-prinsip Syariah di Pasar Modal yang terkait dengan Efek Syariah yang ditawarkan, peraturan ini dan peraturan perundang-undangan di bidang Pasar Modal. Setiap Pihak yang menerbitkan Efek Syariah wajib memenuhi kepatuhan terhadap Prinsip-prinsip Syariah di Pasar Modal yang terkait dengan Efek Syariah yang diterbitkan.

Informasi yang merupakan laporan penting yang harus disampaikan oleh emiten penerbit efek-efek syariah yang menyatakan melakukan kegiatan usaha sesuai dan tidak bertentangan dengan prinsip-prinsip syariah dengan berbagai bentuk instrumen yang diterbitkannya sudah seharusnya merupakan emiten yang juga mendukung atau setidaknya tidak melakukan pelanggaran terhadap kegiatan usaha yang ramah lingkungan. Hal ini terkait dengan salah satu aspek prinsip pilar ekonomi syariah yang bersifat "tawazun" atau keseimbangan, dalam berbagai 
aspek ekonomi, kepentingan duniawi dan ukhrawi, keadilan sosial, maupun dalam makna keseimbangan terhadap pelestarian lingkungan.

Beberapa emiten yang masuk dalam kelompok indeks Sri Kehati sebagai kelompok pendukung ekonomi hijau yang masuk dalam kategori emiten syariah seperti PT Astra International Tbk dan PT Telekomunikasi Indonesia Tbk (TLKM), termasuk perusahaan yang memang tidak bersentuhan langsung dengan usaha yang bergerak dibidang terkait rentan menghasilkan limbah seperti pertambangan, namun dukungan komitmen perusahaan tersebut yang diwujudkan dalam program bukti nyata untuk menjaga lingkungan yang kondusif bagi kesinambungan pembangunan yang berkelanjutan.

Pada prinsipnya, segala jenis instrumen emiten syariah harus konsisten dengan implementasi nilai-nilai ekonomi Islam, termasuk pada komitmen penegakan kegiatan usaha yang ramah lingkungan.

\section{KESIMPULAN DAN SARAN}

\section{KESIMPULAN}

1. Untuk kegiatan Pasar Modal Syariah, Bapepam sebagai pengatur dan pengawas pasar modal di Indonesia berdasarkan Undang - Undang Nomor 8 tahun 1995 tentang Pasal Modal telah menerbitkan Keputusan Ketua Bapepam-LK Nomor Kep-130/BL/2006 dan Nomor Kep-131/BL/2006 telah menerbitkan satu paket regulasi yang terkait dengan penerapan prinsip syariah di pasar modal, yaitu Peraturan Nomor IX.A.13 tentang Penerbitan Efek Syariah dan Peraturan Nomor IX.A.14 tentang Akad-akad yang digunakan dalam Penerbitan Efek Syariah di Pasar Modal. Kegiatan usaha emiten yang terkait dengan dukungannya terhadap kegiatan usaha ramah lingkungan merupakan bagian dari implementasi prinsip-prinsip syariah meskipun dalam ketentuan pelaksanaan ekonomi syariah melalui keputusan BAPEPAM belum dinyatakan secara tegas.

2. Pada prinsipnya, segala jenis instrumen emiten syariah yang diterbitkan di Indonesia saat ini yang meliputi Obligasi Syariah Mudharabah, Obligasi Syariah Ijarah, Saham Syariah, Reksa Dana Syariah, Reksa Dana Indeks 
Syariah, dan Penerbitan Efek Reksa Dana Syariah harus konsisten dengan implementasi nilai-nilai ekonomi Islam, termasuk pada komitmen penegakan kegiatan usaha yang ramah lingkungan.

\section{SARAN}

Meskipun pada prinsipnya filantropi ekonomi Islam termasuk di bidang pasar modal sangat mendukung penerapan upaya pembangunan berkelanjutan yang ramah lingkungan. Hal ini sesuai dengan salah satu pilar etikan bisnis Islam untuk menjaga "Keseimbangan" baik kepentingan individu dan sosial, maupun keseimbangan alam sebagai implementasi konsep Tauhid yang mengakui Allah SWT sebagai penguasa absolut dan manusia sebagai khalifah wajib memakmurkannya dan menghindari kerusakan. Prinsip-prinsip syariah tersebut telah dituangkan dalam ketentuan pelaksanaan Pasar Modal Syariah di Indonesia dalam Keputusan BAPEPAM. Namun ketentuan secara tegas mengenai implementasi kegiatan usaha yang mendukung pembangunan ekonomi berkelanjutan dan ramah lingkunan sebaiknya dicantumkan sebagai bagian laporan yang harus disampaikan oleh emiten yang mengajukan permohonan menjadi bagian dari daftar emiten syariah.

\section{DAFTAR PUSTAKA}

Habib Nazir dan Muhammad Hassanuddin, Ensiklopedi Ekonomi dan Perbankan Syariah, Penerbit Kaki Langit, Bandung, November 2004.

Iswahjudi A. Karim, Implementasi Prinsip-Prinsip Syariah di PasarModal dan Perbankan (Tinjauan Hukum,) KarimSyah Law Firm, Jakarta September 2005.

Mohammad Daud Ali, Hukum Islam, Pengantar Ilmu Hukum dan Tata Hukum

Islam di Indonesia, PT. Raja Grafindo Persada, Cetakan kesembilan, Jakarta,September 2001.

Mubyarto, Etika, Agama, dan Sistem Ekonomi, Artikel Th. 1 Nomor 2, April 2002.

M. Umer Chapra, The Future of Economic : An Islamic Perspektive, dalam 
Muslimin H. Kara

Muslimin H. Kara, Bank Syariah di Indonesia, Analisis Kebijakan Pemerintah Indonesia Terhadap Perbankan Syariah, UII Press, Yogyakarta, 2005.

Mochtar Kusumaatmadja, konsep-Konsep Hukum dalam Pembangunan, PT. Alumni, Bandung, 2002.

Mohammad Hidayat, An Introduction The Sharia Economic Pengantar Ekonomi Syariah, Zikrul

Hakim, Jakarta, Cetakan Pertama : Februari 2010.

Munir Fuady, Hukum Bisnis dalam Teori dan Praktek (Buku Ke dua), PT. Citra Aditya, Bandung, 1996.

Tjiptono Darmadji dan Hendy M. Fakhruddin, edisi 2, Pasar Modal di Indonesia pendekatan Tanya Jawab, Penerbit Salemba Empat, cetakan ketiga Maret 2008.

Daud Silalahi, Pembangunan Berkelanjutan dalam ranka Pengelolaan (termasuk perlindungan) sumber daya alam yang berbasis Pembangunan Sosial dan Ekonomi, Makalah disampaikan pada Seminar Pembangunan Hukum Nasional VIII, Tema Penegakan Hukum dalam Era Pembangunan Berkelanjutan diselenggarakan oleh Badan Pembina Hukum Nasional Departemen Kehakiman dan Hak Asasi Manusia RI Denpasar, 14-18 Juli 2003.

Undang-Undang Nomor 8 tahun 1995 tentang Pasar Modal

Keputusan Ketua Bapepam-LK Nomor Kep-130/BL/2006

Keputusan Ketua Bapepam-LK Nomor Kep-131/BL/2006

Peraturan Bapepam Nomor IX.A.13 tentang Penerbitan Efek Syariah

Peraturan Bapepam Nomor IX.A.14 tentang Akad-akad yang digunakan dalam Penerbitan Efek Syariah di Pasar Modal.

Andreas Timothy, "Berinvestasi Hijau di Lantai Bursa", Media Indonesia, Kamis 12 Mei 2011

Indeks Sri Kehati : Investasi Ramah Lingkungan, http://majalahpialang.com/index.php? show $=$ pialang \&task=detail \&id=8, 